
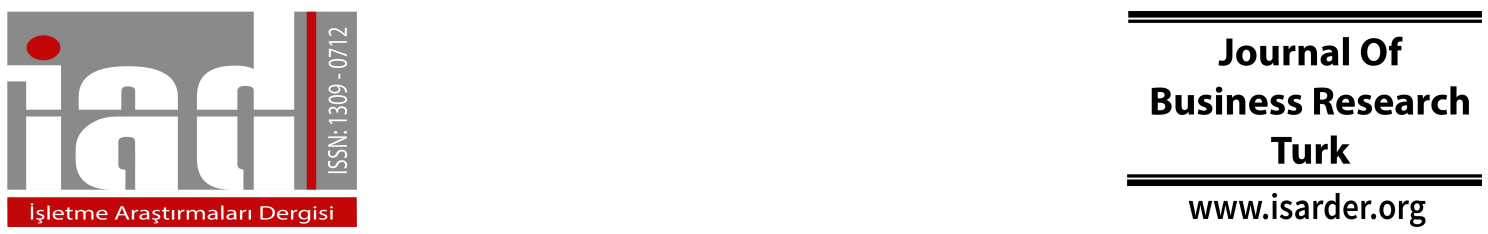

\title{
Factors Affecting the Entrepreneurial Intentions of Women Entrepreneur Candidates: A Structural Equation Model
}

\author{
Hülya ŞEN \\ Eskişehir Osmangazi University \\ Faculty of Sciences and Literature \\ Department of Statistics \\ Eskişehir, Turkey \\ orcid.org/0000-0002-9095-3643 \\ hsen@,ogu.edu.tr
}

\author{
Veysel YILMAZ \\ Eskişehir Osmangazi University \\ Faculty of Sciences and Literature \\ Department of Statistics \\ Eskişehir, Turkey \\ orcid.org/0000-0001-5147-5047 \\ vyilmaz@ogu.edu.tr
}

\author{
Erkan ARI ${ }^{1}$ \\ Dumlupınar University \\ Faculty of Economic and Administrative Sciences \\ Department of Econometrics \\ Kütahya, Turkey \\ orcid.org/0000-0001-6012-0619 \\ erkan.ari@dpu.edu.tr
}

\begin{abstract}
The aim of this study was to reveal factors influencing the entrepreneurial intentions of women entrepreneur candidates using the theory of planned behaviour (TPB). The authors employ the TPB, in which intentions and aspiration towards being an entrepreneur are regarded as resulting from attitudes, perceived behavioural control, and subjective norms. A questionnaire was conducted on 252 women entrepreneur candidates who attend the vocational course, OMEK, which belongs to Eskişehir (Turkey) Odunpazarı Municipality. In the research model that has been proposed within the scope of TPB, the Structural Equation Model (SEM) was used in order to reveal the relationship between the factors influencing entrepreneurial intentions and evaluating the conformity of the model. According to the results of the SEM analysis, it was determined that the latent variables, which are attitudes, subjective norms and perceived behaviour control, have a positive effect on entrepreneurial intentions. In the study, the perceived behavioral control variable was calculated to be $0.38,0.06$ and 0.44 , respectively, direct, indirect and total effect on an aspiration towards being an entrepreneur. In summary, it is determined that the perceived behavior control factor is the most important predictor of entrepreneurial intention and an aspiration towards being an entrepreneur factor.
\end{abstract}

Keywords: Entrepreneurship, Women entrepreneur candidate, Theory of planned behaviour (TPB), Structural equation modelling (SEM)

\footnotetext{
${ }^{1}$ Sorumlu yazar
} 


\section{Introduction}

From the 1980s, the understanding of entrepreneurship has gained strength by virtue of the latest technological developments and economic expectations (Yenilmez, 2012). In the literature, entrepreneurship is identified in different ways. According to Bird (1989), it is a process to establish a new profit-making institution or to create new goods and services. According to Mueller and Thomas (2000), entrepreneurship is a process by which an opportunity can be perceived and evaluated. Meanwhile, Lounsbury (1998) described it as an activity to examine alternative production project to take the opportunity and to provide their optimization (Y1lmaz and Sünbül, 2009).

In the economy of a globalizing world, entrepreneurship has gained importance. The improvement and development of a country depends on training entrepreneurs who have the ability to conform rapidly changing conditions and are able to contribute to economic growth (Durukan, 2007; Mutlu, 2014). Factors affecting entrepreneurship, which are of great importance for economic markets, can be listed as culture, family and social environment, legal, political administrative and financial environment, education and psychological factors.

Different occupational groups have defined various dynamic functions for the development and strength of a country. According to economists, entrepreneur defined as a way of deploying resources that collect economic elements and products and as a result of this production, earns money. For an industrialist and a businessman, an entrepreneur is termed as fearless investor; an ambitious and passionate competitor; a client or an ally. According to a trader, it is termed as a person who has invested and taken risks, and competed and earned money. For a psychologist, entrepreneurs are highly motivated people who want to acquire something, attain something, attempt something, and share the authority that is in others' hands (Hisrich and Peters, 1998; Yılmaz and Sünbül, 2009).

In traditional Turkish culture, even though a woman is often seen as the family member who does the housework, takes care of the children, and does the cooking, expectations from women have increased with the changing world order. It is expected that a woman should contribute to the economy. Women comprise half the Turkish population and it is a big loss for the country not to be able to benefit from their knowledge, ability and experience (Keskin, 2014).

Women's entrepreneurial activity in Turkey, government policies developed for households to increase their income "women from attempting to establish small businesses" are formed. Increased efforts to provide additional income for women and to work in paid jobs have accelerated the entry of women into economic activities. In Turkey, however, women in particular, who are not adequately educated and do not have skills to do the jobs for which they have applied, have a weak chance of finding a job, so it eventually leaves woman no choice but doing their own business (Soysal, 2010).

In Turkey, where the participation rate of women in the labor force is one third of the rate of men, the participation rate of women in the employment market cannot be increased. The proportion of women participating in the labor force in Turkey is not only behind that of Europe but also other countries. According to the data of Turkish Statistical Institution (TUIK), the women population between the ages of 15 and over 29 , the number of women participating in the labor force is 9,225,000. A total of 
$8,058,000$ women in the labor force are employed, the rest $(1,167,000)$ are unemployed. The statistics show that, for women, labor force participation is $31.5 \%$. According to International Labor Organization (ILO) data from 2012, the labor force participation rate of women, who are over the age of 15 , is $53 \%$ in developed countries (including the European Union), 53\% in Latin America and the Caribbean and more than $50 \%$ in South Asia. Meanwhile, in Turkey, this proportion was $29.5 \%$ in $2012,31.8 \%$ in 2013 and $31.5 \%$ in 2015 (Turkish Statistical Institution (TUIK), 2015: Woman Basic Labor Force Indicators).

World Bank Country Director, Martin Raiser, indicates that an increase in women employment considerably increases economic growth, while decreasing poverty. The World Bank estimates that an increase of only 6 points in the proportion of full-time employment for women can increase revenues by $7 \%$ and decrease poverty by $15 \%$ (Milliyet [Newspaper], 9 February, 2014). When viewed from this standpoint, the increase in women employment, women participation in the labor force and the proportion of entrepreneurial women in Turkey, such as that in other developed countries, is extremely important with regard to the development of the country's economy and a decrease in poverty. From this point of view, as in other developed countries, the development of the economy in Turkey is also very important in terms of poverty reduction, women's employment, women's participation in the workforce and the rate of entrepreneurial women.

In general terms, the women entrepreneur can be defined as a woman who establishes a business, or organizes and operates a business. Yalman and Gündoğdu (2014) defined women entrepreneurs as women who have their own business in a market economy, who work unaccompanied or who work with employees, who produce and buy goods and services, who seek out their own resources, who are able to adapt to new conditions and who attempt to gain experience.

When defining a women entrepreneur, it is necessary to include not only women employers, but also all women making an effort in this field throughout the country. Within the scope of women entrepreneurs, women who are self-employed should be discussed as well. However, according to the 10th Development Plan Report, performance of the women who do not take a part in the economic life in Turkey with respect to entrepreneurship as required, is underwhelming. Hence, in 2012, the rate of women employers who are self-employed is $12.1 \%$, and only $14.9 \%$ of the total number of entrepreneurs is women and the rate of women entrepreneurs is $10.7 \%$. When looking at the general situation in Turkey, by 2012, 78.7\% of women entrepreneurs (totally 94.000 women employers) are in the services sector, the $12.8 \%$ of women entrepreneurs are in industrial and $8.5 \%$ are in the agricultural sector of 94.000 women employers; as for the 788,000 women who are self-employed, $30.3 \%$ in the services sector, $17.3 \%$ in the industrial sector, and $52.4 \%$ in the agricultural sector are engaged in an activity (Ministry of Science, Industry and Technology General Directorate of Productivity Monthly Review, 2015).

Because of the limited access to financial resources, women's entrepreneurship is oriented towards the service sector. The number of is quite low in sectors based on industry, machines and production. The most important underlying reasons are the opportunities that arise due to the cultural, financial and socio-economic environment in the country. 
When looked what guides women towards entrepreneurship and leads them to establish their own business, one can be see a sequence of factors, rather than only one driving force. For example, the following can be taken into account: psychological motivations such as success, independence, locus of control and economic motivations, financial independence and discontent with working conditions, disappointment with her career path, an absence of career opportunities, the glass-ceiling syndrome or the structure of a flexible working model (Dzisi, 2008).

Women entrepreneurship, which has recently showed a rapid growth in Turkey, has gained importance by virtue of technological developments and economic expectations. Having ability or education may not guarantee someone being an entrepreneur. Also, the social environment should be well defined. There is a need for women entrepreneurs who are talented, productive, have successfully completed their education, have knowledge of up-to-date technology, and understand the needs of society. Therefore, some of the municipalities in Turkey help women entrepreneurs to run their own business following the completion of offered vocational courses.

Özden et al (2008) and Kalkan (2011) discussed that the psychological demographic characteristics of individuals an attempt is made to explain entrepreneurial intentions. They stated that psychological factors such as values, attitudes, experiences, play in influencing subconscious behaviours have a significant role in determining their entrepreneurial intentions. Recently also psychological characteristics have been considered as important characteristics affecting entrepreneurial intentions. According to literature, studies concerning the factors influencing the intentions of women entrepreneur candidates are generally based on different theoretical evaluations on women entrepreneurship, the importance of women entrepreneurs in global economic competition; the problems of women entrepreneurship and suggestions for their solution. Consequently, the aim of this study is to measure the factors influencing the entrepreneurial intentions of women by using of the theory of planned behaviour. First, a structural model and hypotheses were designed and then the fit of the model was analyzed using LISREL 8.80 .

\section{Literature Review}

Rajib et al. (2017) researched that endeavours to comprehend the young science and technology graduates' intention toward pursuing an entrepreneurial career in a developing nation i.e., India. They used a modified version of Ajzen's theory of planned behaviour. They attempted to integrate three additional constructs (perceived career option, entrepreneurial knowledge and entrepreneurial personality traits) to explain the relationship between a list of antecedents and entrepreneurial intention. They found a positive but relatively weak influence of subjective norms on intention formation.

Arshad et al (2016) investigated the effect of entrepreneurship self-sufficiency and social norms on the entrepreneurial intentions of individuals by integrating the theoretical framework of gender diagram into the theory of planned behavior. SEM was used in the analysis of the work. The results show that perceived entrepreneurship selfefficacy has more influence than men's attitude towards entrepreneurship over women's attitude, but perceived social norms have greater influence on entrepreneurial attitudes towards women.

In their survey, Austin and Nauta (2016) stated exposure to entrepreneurial role models (operationalized in terms of both the number of role models known and the 
intensity of interactions with one's most influential role model) and self-efficacy were predictors of women's entrepreneurial intentions. In 620 women college students, selfefficacy and many entrepreneurial role models were both related to stronger entrepreneurial intentions. A total 105 women who had at least one entrepreneurial role model, the intensity of interactions with the most influential of those role models was also related with entrepreneurial intentions. Self-efficacy intervened in the relationships between both forms of role-model exposure and entrepreneurial intentions that were consistent with social cognitive career theory.

Kautonen et al. (2015), in their paper, stated the convenience and durability of planned behaviour theory (TPB) in the estimation of business beginning intentions and subsequent behavior based on longitudinal survey data (2011 and 2012; $n=969)$ from the adult population of Austria and Finland. In so doing, the study demonstrated two inabilities in research: the limited scope of samples used in the majority of prior studies and the scarcity of investigations studying the translation of entrepreneurial intentions into behaviour. The research discussed conceptual and methodological issues related to studying the intention-behaviour relationship and outlines avenues for future research.

Mei et al. (2015) investigated the influence of planned behavior and personal variables on in order to explain and improve low among tourism students in China. A total of 109 tourism students were surveyed to find the key factors affecting their entrepreneurial intention by factor analysis. Multi-group analysis further showed that there are differences between personal attitude, subjective norm and perceived behavioural control according to different personal variables. The results highlight the importance of taking a subdividing approach when researching the factors that influence entrepreneurial intention.

Kautonen et al (2013) contributed to the occupational choice literature pertaining to entrepreneurship by planning TBP to predict entrepreneurial behaviour. This article provided a full test of the TBP in the prediction of business start-up intentions and subsequent behaviour based on two-wave survey data (2006 and 2009) from the working-age population in Finland. The econometric result support the predictions outlined in the TBP: attitude, perceived beahvioural control and subjective norms are significant predictors of entrepreneurial intention; and intention and perceived behavioural control are significant predictors of subsequent behaviour.

Koçoğlu and Hassan (2012) have tested the cross-cultural generalizability of how well planned behaviour theory (TPB) would predict entrepreneurial intention (EI) between Turkish and Pakistani University students, in their study. In conclusion, the results showed that the relationships among the TPB components were equally intense and comparable across Pakistani and Turkish cultures - the only exception being the relation of social norms with intentions. In addition to this, SN (subjective norm) would prove its impact on EI through both PA (personal attitude) and PBC (perceived behavioural control) but not directly on intention.

Lo et al. (2012) wanted to experimentally compare and contrast the entrepreneurship intents between men and women engineering students with the effort of entrepreneurship education. The planned behaviour theory (TPB) was used as the theoretical basis of this study. A total of 411 engineering students from three universities in Hong Kong, 303 men and 108 women, were included in this study. As a result, research showed that TPB was suitable to state entrepreneurial intention of 
students for both women and males. Moreover, male and women students were different in terms of entrepreneurial attitudes, social norms and entrepreneurial intentions even they experienced by taking entrepreneurial education.

Engle et al. (2010) presented entrepreneurship intent in 12 countries based using planned behaviour theory. The research findings showed that TBP was an important model for estimating the entrepreneurial intention in the countries in which researches have made. In the research, it was stated that, especially social norm factor was an important factor to determine the entrepreneurship intent (EI).

Liñán and Chen (2009) used the planned behaviour theory of Ajzen to establish an entrepreneurial intention questionnaire (EIQ) and examined its psychometric properties. The entrepreneurial intention model is then tested on a 519-individual sample from 2 different countries: Spain and Taiwan. The Entrepreneurial Intention Questionnaire (EIQ) and structural equation techniques were used to try to overcome previous research limitations. The role of culture in explaining motivational perceptions was specifically considered. The results of research stated that entrepreneurial intention questionnaire (EIQ) properties were satisfactory and strong support for the model was found. Relevant views were derived about how cultural values modify the way individuals in each society understand entrepreneurship.

Gelderen et al. (2008), in their research, organized to state a detailed experimental investigation of the entrepreneurial intents of business students. They employed the planned behaviour theory (TPB), in which intents were regarded as a result of attitudes, perceived behavioural control, and subjective norms. The results demonstrated that the two most important variables to explain entrepreneurial intents were entrepreneurial alertness and the importance that was attached to financial security.

Shook and Bratianu (2008) studied about the entrepreneurial intentions of Romanian students by using the theory of planned behaviour (TPB). They have analysed survey data from 324 Romanian students to evaluate for mediation by using regression analyses. While some of their findings were inconsistent with the theory of planned behaviour, some of them were consistent. As it was expected, they concluded that self-efficacy and eagerness regards with raising an enterprise were positively associated with entrepreneurial intention. Nevertheless; stunningly, they deduced that the more supportive the referents of students were less likely the students were to have intents of beginning a business.

Kolverid and Isaksen (2006) emphasized on new businesses, which is begun from a little point. To formulate hypotheses regard with the self-employment intentions and subsequent entry into self-employment, the Theory of Reasoned Action and the Theory of Planned Behavior are used. The hypotheses were tested using longitudinal data from 297 Norwegian business founders. As a conclusion, the results showed that distinctive thoughts related to self-employment determined the attitudes in accordance with the self-employment, that attitude and subjective norm stated intents to become selfemployed, and that intents to become self-employed stated actual entry into selfemployment. Krueger et al. (2000), in the study that was with American students in America, in TPB model and the study that is estimated being entrepreneur behavior, it was emphasized that there were strong factors on attitude, subjective norm, perceived feasibility and entrepreneurship intent. 


\section{Method}

\subsection{Theoretical framework}

Ajzen (1988 and 1991) developed a model of planned behavior and reported this model to be a highly effective predictor of a wide range of behavior. There are number of studies that apply all dimensions of Ajzen's planned behavior model (TPB) to the area of entrepreneurial intent - the intent to start one's own business. These studies support the usefulness of Ajzen's theory and his view that behavioral intent is a powerful predictor of the targeted behavior.

It was referred that behaviour of an individual was not solely based on their will, but also by factors such as perceived behavioural control, TPB improved on the theory of reasoned action (TRA) (Ajzen and Fishbein, 1980). Liska (1984) discussed that the implementation of many behaviours would be compelled by the appropriate opportunities, abilities and resources. In this regard, in addition to the variables in TRA, TPB involved a third variable to the model, i.e. the perceived behavioural control that measured the ability of the individual to perform the behaviour.

Being one of the theories widely was accepted by researchers, and developed to explain behaviour in many fields such as sociology, psychology, education and marketing, planned behaviour theory (TPB) is the most comprehensive among the behavioural models, and one which describes behaviours with a few variables (Gelderen et al., 2008; Shook and Bratianu, 2008).

According to TPB, there are three factors that affect behaviour. These are: attitudes toward behaviour (personal attitude and individual conduct), subjective norms (influence of significant others; perceived social pressure) and perceived behavioural control (Ajzen, 1991).

Individuals' attitudes are taken example in such a way that they always form a bridge between an individual's beliefs and intentions. The attitude of an individual, regarding certain behaviour affects the individual's intention toward performing that behaviour, which in turn affects the actual behaviour (Lee et al., 2007). Subjective norms or social pressure is a function of the perceived expectations of persons or groups close to the individual or the significant others (such as friends, neighbours etc.), and the desirability of an individual in meeting these expectations (Fischbein and Ajzen, 1975). In social psychology, intention is the most crucial aspect of behaviour (Abraham and Sheeran, 2003).

TPB is preferred, as it has proved to be useful in much research on entrepreneurial intentions (Krueger et al., 2000; Kolverid and Isaksen, 2006; Shook and Bratianu 2008; Koçoğlu and Hassan, 2012). Indeed, Ajzen and Fischbein (2000) accepted that there are factors other than the TRA: for example, experiences and demographic variables may influence behaviour. Additionally, they claimed that such effects are indirect, and governed by the elements of model. Moreover, TPB also allows additional variables to be united in the model (Ajzen, 1991).

\subsection{Questionnaire design and data collection}

In the research, which has been made by CNBC-e Business Journal, women entrepreneurs who live in the centre of Eskişehir, 750,000 population, which is the third most livable city of Turkey, consist the research sample. Since there is no sampling framework, probabilistic sampling methods could not be used in the study. Because of these constraints, the research sample is identified as 252 women entrepreneurs, who 
continue to the Vocational Course of Eskişehir Odunpazarı Municipality (OMEK) and volunteered to complete the questionnaire, and it is assumed that this sample may represent the universe. In 2004-2005 Academic Year, the OMEK project, that began with four course centers, 450 course attenders in 18 branches, today either the number of the corsers or the number course centre and class, is one of the big education projects of Turkey. OMEK that is defined as "an education organization for adults which is carried out with the widespread principles" rehabilitation centre and an enormous culture centers besides of being an important reference for art and professional training, work and occupation.

OMEK, which is one of the important social projects of Eskişehir Odunpazarı Municipality, trains now 7,500 course attendees in 57 branches in 15 course centers. The questionnaire was conducted at OMEK by interviewing the candidates face-to-face. The data collection tool used for the study was prepared with various statements of Shook and Bratianu (2008), Koçoğlu and Hassan (2012), Lo et al. (2012) and Austin and Nauta (2016). Demographic characteristics take part in the first part of questionnaire form which is prepared for study, such as age, job of father, education level, number of children, marital status etc. of women entrepreneur candidates. In the second part, it is sought an answer for entrepreneurial intentions and difficulties that confront in entrepreneurship. In the study, a five-point Likert scale was used for attitude statements (1: strongly disagree; 5: strongly agree). After experts opinion are received for the data collection tool the pilot study was carried out with 37 entrepreneur candidates and problematic questions were removed from the questionnaire, while others questions were restored. The questionnaire involved five factors, including: "A: Attitude", "B: Subjective norm", "C: Perceived Behaviour Control", "D: Intention", "E: An aspiration towards being an entrepreneur". Reliability analysis was made in order to evaluate the dependability of the evaluation tool and the Cronbach's Alpha reliability coefficient was found to be 0.88 .

The statements in the questionnaire were used to explain a range of attitudes like: "To be an entrepreneur would bring me social status," "Entrepreneurship gives me an opportunity to act independently," "The reason for being an entrepreneur is to earn money." Composite reliability of Attitude factor is $(\mathrm{CR}=0.72)$ and explained variance is $(\mathrm{AVE}=0.52)$. Two statements were used in order to explain subjective norms: "In my entrepreneurship career, if I meet with difficulties, my family motivate me positively" and "My family approve of my decision to be entrepreneur." Composite reliability of subjective norms is $(\mathrm{CR}=0.69)$ and explained variance is $(\mathrm{AVE}=0.65)$. Three statements were used in order to perceive behaviour control size: "I know how to develop an entrepreneurial project," "I think that I have enough knowledge to be an entrepreneur", "I think that my business ideas are sufficiently creative to be an entrepreneur." Composite reliability for perceived behavior control is $(\mathrm{CR}=0.73)$ and explained variance is $(\mathrm{AVE}=0.48)$. Four statements in the questionnaire were used in order to explain intention: "I imagine myself as an entrepreneur one or other day," "If I find an opportunity, I may be an entrepreneur", "I feel ready myself to be an entrepreneur", "I have strong feelings in my heart to establish a business." Composite reliability of intention is $(\mathrm{CR}=0.82)$ and explained variance is $(\mathrm{AVE}=0.52)$. The level of aspiration towards being an entrepreneur is measured by one item: "I will realize entrepreneurship activities for the next twelve months." 


\subsection{The research model and design of hypotheses}

Entrepreneurial intention refers to the intention of an individual to start a new business. A number of researchers including Krueger (1993), Kolvereid (1996), Tkachev and Kolvereid (1996) and Krueger et al. (2000), among others, have recognized the important role played by entrepreneurial intent. TBP has been successfully used in the literature to predict entrepreneurial behavior; in a USA sample (Krueger et al., 2000), in France (Fayolle, 2004), in Norway (Kolvereid, 1996), Russia (Takachev and Kolvereid, 1999), in Sweden, Finland, Thailand, the UK, and the USA (Autio et al., 1997, 2001), and in Ireland and the USA (Depillis and Reardon, 2007). For this reason, we chose TBP to predict entrepreneurial intentions of women entrepreneur candidates.

The research model that has been used in the study was given in Figure-1. The research model which was used in this study was constituted from the studies of Kruger et al. (2000), Brindley (2005), Gelderen et al. (2008), Shook and Bratianu (2008), Liñán and Chen (2009), Engle. (2010), Koçoğlu and Hassan (2012), Chasserio et al. (2014), Kautonen et al. (2015)

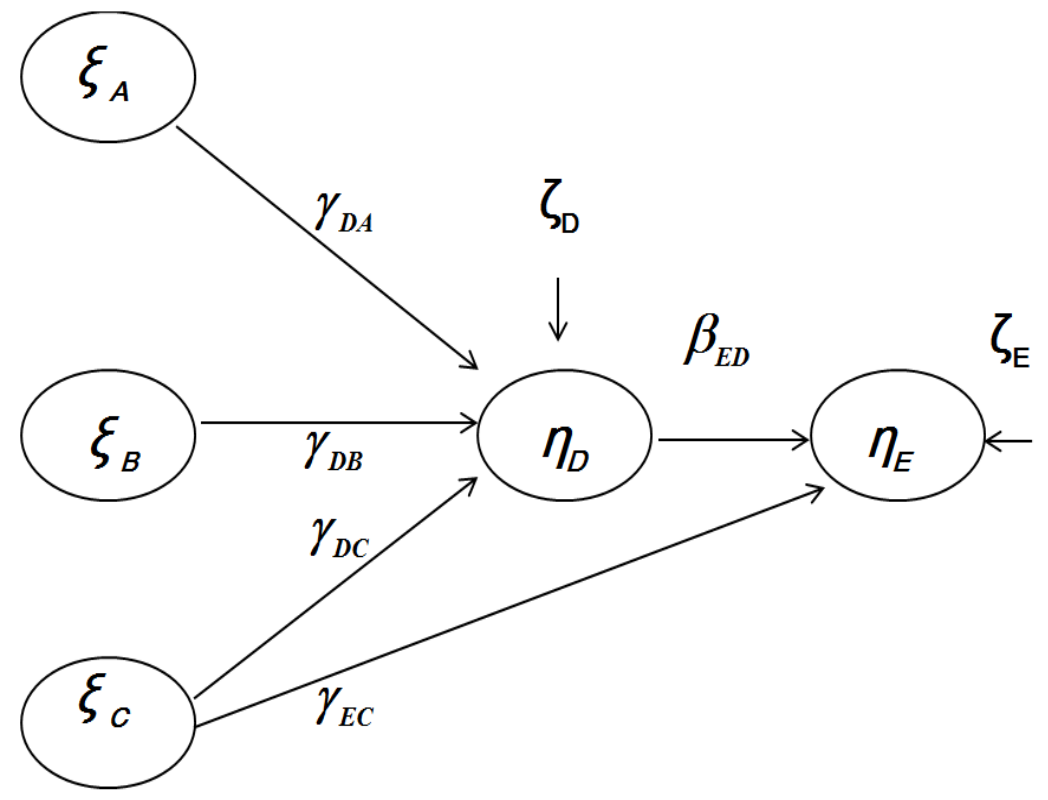

Figure 1. Proposed Research Model

A: Attitude; B: Subjective Norm C: Perceived Behaviour Control; D: Intention

E: An Aspiration Towards Being An Entrepreneur

In most studies, it has been determined that intentions are related to entrepreneurship and in particular that concerned with individuals attitudes (Kruger et al., 2000; Gelderen et al., 2008; Engle et al., 2010; Igbal et al.; 2012; Kautonen et al., 2015). Subjective norms and perceived behavioural control affect the entrepreneurial intention. Hypotheses and offered research model based upon hypotheses are constituted in accordance with the results obtained from related studies.

It is aimed to search whether there is a semantic relation between attitudes concerning entrepreneurship and entrepreneurial intentions of women entrepreneur candidates in the study. The hypothesis below may be offered in accordance with this aim: 
$\mathbf{H}_{1}$ : There is a relation between attitude concerning entrepreneurship of women candidates and entrepreneurial intentions.

Mckenzie-Mohr and Smith (1999) defined the interference effect not as persuading people, as inspiring moral compass to execute an act. Many studies show the importance that subjective norm (social pressure or immediate environment view) in interferences concerning entrepreneurship (Kolverid and Isaksen, 2006; Koçoğlu and Hassan, 2012; Lo et al., 2012;).

According to Ajzen and Fishbein (1975), an individual, he/she perceives what others think about is important what he/she does, he/she is prone to show his/her specific behaviour. In the light of this information, the hypothesis below may be offered:

$\mathbf{H}_{2}$ : There is a relation between Subjective norms concerning entrepreneurship of women candidates and entrepreneurial intentions.

In many researches, it has seen that perceived behavioural control affect entrepreneurship intention and behaviour about being an entrepreneur or will (Shook and Bratianu, 2008; Engle et al., 2010; Kautonen et al., 2015). In the light of this information, a hypothesis can be proposed for entrepreneurship intention and how aspiration towards becoming an entrepreneur affects:

$\mathbf{H}_{3}$ : Perceived behavioural control affects the intentions concerning entrepreneurship of women candidates.

$\mathbf{H}_{4}$ : Perceived behavioural control affects an aspiration towards being an entrepreneur of women candidates.

Ajzen (1991) and Ajzen and Fischbein (1980, 2000), in their studies, verified the relation between intention and aspiration to reveal certain behaviour. Finally, the hypothesis below is asserted with the assumption that is a determinant of the wish to reveal certain behaviour:

$\mathbf{H}_{5}$ : Entrepreneurial intentions affect an aspiration towards being an entrepreneur of women candidates.

\section{Results}

\subsection{Descriptive Statistics}

Of the women entrepreneur candidates who volunteered for the research, $20.9 \%$ were in the 18-24 age group; $21.3 \%, 25-35$ age group; $16.2 \%, 36-45$ age group; $24.9 \%$, 46-55 age group; $14.2 \%, 56-65$ age group and $2.4 \%$ age of 65 . A total of $13 \%$ of the women entrepreneur candidates were primary school graduates; $8.3 \%$ were secondary school graduates; $36 \%$ were high school graduates; $22.5 \%$ had bachelor degrees and $2 \%$ were postgraduates. While $57.3 \%$ of the women entrepreneur candidates were married; $32.8 \%$ were single; $6.3 \%$ were divorced, $3.2 \%$ has lost his/her husband/wife. Of the women entrepreneur candidates, $6.7 \%$ had three children; $34.8 \%$ had two children and $16.6 \%$ had one child. The remaining $41.9 \%$ of the candidates had no child. When looking at fathers' occupations of the women entrepreneur candidates, $20.6 \%$ were public employees, $11.9 \%$ were private sector employees. It was also seen that $8.3 \%$ were business owners; $8.7 \%$ were not working, and 50.65 were in other categories. A total of $13.8 \%$ of the women entrepreneur candidates stated that they were courageous; $17.8 \%$ said they were creative; $19.8 \%$ described themselves as self-confident; $21.3 \%$ had researcher souls; $13 \%$ said they were curious, and $13.8 \%$ said they were critical. While $24.5 \%$ of the candidates stated that they had previously been taught about 
entrepreneurship, $68.8 \%$ of them said they had not. Of the women entrepreneur candidates $31.2 \%$ stated that there was an entrepreneur in their family, while $68.8 \%$ said that nobody in their family was is an entrepreneur.

\subsection{Results of the Structural Equation Model}

There were 2 endogenous variables as $(\mathrm{m}=2)$ and there were 3 exogenous variables as $(n=3)$. The detailed specific SEM can be prepared according to the form of matrices that are shown below, depending on Equations 1-3.

Structural equation:

$$
\begin{aligned}
& \eta=\mathrm{B} \eta+\Gamma \xi+\zeta \\
& {\left[\begin{array}{l}
\eta_{D} \\
\eta_{E}
\end{array}\right]=\left[\begin{array}{cc}
0 & 0 \\
\beta_{E D} & 0
\end{array}\right]\left[\begin{array}{l}
\eta_{D} \\
\eta_{E}
\end{array}\right]+\left[\begin{array}{ccc}
\gamma_{D A} & \gamma_{D B} & \gamma_{D C} \\
0 & 0 & \gamma_{E C}
\end{array}\right]\left[\begin{array}{l}
\xi_{A} \\
\xi_{B} \\
\xi_{C}
\end{array}\right]+\left[\begin{array}{l}
\xi_{D} \\
\xi_{E}
\end{array}\right]}
\end{aligned}
$$

where $\eta$ (eta) is an $(2 \times 1)$ column vector of $m$ endogenous variables, $\xi$ (xi) is an $(n \times 1) \quad$ column vector of 3 exogenous variables, $\beta$ (beta) is a matrix (2×2) of coefficients that are related to the direct effects of endogenous variable on another endogenous variable, $\Gamma$ (gamma) is a matrix $(2 \times 3)$ of coefficients associated with the direct effects of exogenous variable on another endogenous variable, and $\zeta$ (zeta) is a column vector of error terms associated with endogenous variables.

Measurement equations:

$\mathrm{p}=5$, measured endogenous variables, and $\mathrm{q}=8$, measured exogenous variables.

$\boldsymbol{y}=\Lambda_{\boldsymbol{y}} \boldsymbol{\eta}+\boldsymbol{\varepsilon}$

$$
\left[\begin{array}{c}
D_{1} \\
D_{2} \\
D_{3} \\
D_{4} \\
E_{1}
\end{array}\right]=\left[\begin{array}{cc}
\lambda_{D 1}^{y} & 0 \\
\lambda_{D 2}^{y} & 0 \\
\lambda_{D 3}^{y} & 0 \\
\lambda_{D 4}^{y} & 0 \\
0 & \lambda_{E 1}^{y}
\end{array}\right]\left[\begin{array}{c}
\eta_{D} \\
\eta_{E}
\end{array}\right]+\left[\begin{array}{c}
\varepsilon_{D 1} \\
\varepsilon_{D 2} \\
\varepsilon_{D 3} \\
\varepsilon_{D 4} \\
\varepsilon_{E 1}
\end{array}\right]
$$

$$
x=\Lambda_{X} \xi+\delta
$$

$$
\left[\begin{array}{l}
A_{1} \\
A_{2} \\
A_{3} \\
B_{1} \\
B_{2} \\
C_{1} \\
C_{2} \\
C_{3}
\end{array}\right]=\left[\begin{array}{ccc}
\lambda_{A 1}^{x} & 0 & 0 \\
\lambda_{A 2}^{x} & 0 & 0 \\
\lambda_{A 3}^{x} & 0 & 0 \\
0 & \lambda_{B 1}^{x} & 0 \\
0 & \lambda_{B 2}^{x} & 0 \\
0 & 0 & \lambda_{C 1}^{x} \\
0 & 0 & \lambda_{C 2}^{x} \\
0 & 0 & \lambda_{C 3}^{x}
\end{array}\right] \cdot\left[\begin{array}{l}
\xi_{A} \\
\xi_{B} \\
\xi_{C}
\end{array}\right]+\left[\begin{array}{c}
\delta_{A 1} \\
\delta_{A 2} \\
\delta_{A 3} \\
\delta_{B 1} \\
\delta_{B 2} \\
\delta_{C 1} \\
\delta_{C 2} \\
\delta_{C 3}
\end{array}\right]
$$

in which $\mathrm{y}_{(5 \times 1)}$ and $\mathrm{x}_{(8 \times 1)}$ are the column vectors of 5 measured endogenous variables, and 8 measured exogenous variables, respectively; in which $\mathrm{x}$ and $\delta$ (delta) 
are column q-vectors that associated with the observed exogenous variables and errors, in order of; $\Lambda \mathrm{x}$ (lambda) is a ( $8 \times 3)$ structural coefficient matrix for the influences of the latent exogenous variables on the observed variables; y and $\varepsilon$ (epsilon) are column p-vectors that associated with the observed endogenous variables and errors, in order of; $\Lambda y$ is a ( $5 \times 2$ ) structural coefficient matrix for the influences of the latent endogenous variables on those observed.

The assumptions of the standardized parameter taken as a result of SEM for the research model are given in Table 1 . The $t$ test is supported by hypotheses $\mathrm{H}_{1}, \mathrm{H}_{2}, \mathrm{H}_{3}$, $\mathrm{H}_{4}, \mathrm{H}_{5}$. In assessing the cohesion of the obtained model for the research model, different goodness of fit indices, which have different statistical functions can be used. The most frequently used indices among those proposed are the likelihood ratio chisquare statistic $\left(\chi^{2}\right)$, RMSEA (Root Mean Square Error Approximation), GFI (Goodness of Fit Index), IFI (Incremental Fit Index); CFI (Comparative Fit Index), NNFI (Non-Normed Fit); NFI (The Normed Fit Index) and SRMR (Standardized RMR). (For details of cohesion criteria, see: Jöreskog and Sörbom, 1996; SchermellehEngel and Moosbrugger, 2003.) The cohesion criteria of the research model of the study were evaluated as $\chi^{2} / d f=2.05 ;$ RMSEA $=0.065 ;$ GFI $=0.93 ;$ IFI $=0.97 ;$ CFI $=0.97$; $\mathrm{NFI}=0.95 ; \mathrm{NNFI}=0.96$; $\mathrm{SRMR}=0.05$. Analysis of the cohesion criteria refer that SEM remains within acceptable bounds; therefore, it can be supposed a valid model.

Table1. SEM Results for the Proposed Research Model

\begin{tabular}{|c|c|c|c|}
\hline Factors / Items & $\begin{array}{l}\text { Standard } \\
\text { weight }\end{array}$ & t-value & $R^{2}$ \\
\hline \multicolumn{4}{|l|}{$\begin{array}{l}\text { Factor A: Attitude } \\
(\text { Cronbach's } \alpha=0.69 ; C R=0.72 ; A V E=0.52)\end{array}$} \\
\hline $\mathrm{A}_{1}$ : To be an entrepreneur brings me social status. & 0.80 & $12.68 * *$ & 0.64 \\
\hline $\begin{array}{l}\mathrm{A}_{2} \text { : Entrepreneurship enables me an opportunity to act } \\
\text { independently. }\end{array}$ & 0.71 & $11.26 * *$ & 0.51 \\
\hline $\begin{array}{l}\mathrm{A}_{3}: \text { The reason why being an entrepreneur is earning } \\
\text { money. }\end{array}$ & 0.51 & $7.66^{* *}$ & 0.26 \\
\hline \multicolumn{4}{|l|}{$\begin{array}{l}\text { Factor B:Subjective Norm } \\
\text { (Cronbach's } \alpha=0.78 ; C R=0.69 ; A V E=0.65)\end{array}$} \\
\hline $\begin{array}{l}\mathrm{B}_{1} \text { : In my entrepreneurship career, if I meet with } \\
\text { difficulties, my family motivate me positively. }\end{array}$ & 0.76 & $11.83 * *$ & 0.58 \\
\hline $\mathrm{B}_{2}$ : My family approve my decision to be entrepreneur. & 0.84 & $13.01 * *$ & 0.71 \\
\hline \multicolumn{4}{|l|}{$\begin{array}{l}\text { Factor C: Perceived Behaviour Control } \\
\text { (Cronbach's } \alpha=0.72 ; C R=0.73 ; A V E=0.48 \text { ) }\end{array}$} \\
\hline $\begin{array}{l}\mathrm{C}_{1} \text { : I know how I develop a project about } \\
\text { entrepreneurship. }\end{array}$ & 0.59 & $9.18 * *$ & 0.35 \\
\hline $\begin{array}{l}\mathrm{C}_{2} \text { : I think that I have enough knowledge to be an } \\
\text { entrepreneur. }\end{array}$ & 0.71 & $11.29 * *$ & 0.50 \\
\hline $\begin{array}{l}\mathrm{C}_{3} \text { I think that my business ideas are creative to be an } \\
\text { entrepreneur. }\end{array}$ & 0.76 & $12.16^{* *}$ & 0.57 \\
\hline \multicolumn{4}{|l|}{$\begin{array}{l}\text { Factor D: Intention } \\
\text { (Cronbach's } \alpha=0.81 ; C R=0.82 ; A V E=0.52)\end{array}$} \\
\hline $\mathrm{D}_{1}$ : I imagine myself as an entrepreneur one or other day. & 0.70 & & 0.49 \\
\hline $\mathrm{D}_{2}$ : If I find an opportunity, I may be an entrepreneur. & 0.74 & $10.16^{* *}$ & 0.55 \\
\hline
\end{tabular}




\begin{tabular}{|c|c|c|c|}
\hline $\mathrm{D}_{3}:$ I feel ready myself to be an entrepreneur. & 0.76 & $10.40 * *$ & 0.58 \\
\hline $\begin{array}{l}D_{4} \text { : I have strong feelings in my heart to establish a } \\
\text { business. }\end{array}$ & 0.69 & $9.61 * *$ & 0.48 \\
\hline \multicolumn{4}{|l|}{ Factor E: An aspiration towards being an entrepreneur } \\
\hline$E_{1}:$ I will realize entrepreneurship activities next one year. & 0.81 & & 0.66 \\
\hline \multicolumn{4}{|l|}{ Hypotheses } \\
\hline $\begin{array}{l}\mathrm{H} 1: \mathrm{A} \rightarrow \mathrm{D} \\
2.47 * *\end{array}$ & & 0.24 & \\
\hline $\mathrm{H} 2: \mathrm{B} \rightarrow \mathrm{D}$ & & 0.30 & \\
\hline $\begin{array}{l}3.36^{* *} \\
\mathrm{H} 3: \mathrm{C} \rightarrow \mathrm{D} \\
3.38^{* *}\end{array}$ & & 0.33 & \\
\hline $\begin{array}{l}\mathrm{H} 4: \mathrm{C} \rightarrow \mathrm{E} \\
3.18^{* *}\end{array}$ & & 0.38 & \\
\hline $\begin{array}{l}\mathrm{H} 5: \mathrm{D} \rightarrow \mathrm{E} \\
1.68^{*}\end{array}$ & & 0.19 & \\
\hline Structural equations & & & \\
\hline$D=0.24 \xi_{A}+0.30 \xi_{B}+0.33 \xi_{C}+0.49$ & & & 0.51 \\
\hline$E=0.38 \xi_{c}+0.19 \eta_{D}+0.63$ & & & 0.27 \\
\hline
\end{tabular}

The path diagram of the structural equation model (SEM) is shown in Figure 2. The analysis of the results, which are given in Table 1 and Figure 1, indicate that the latent exogenous variable. Structural equations are given in equations 4 and 5 .

$$
\begin{aligned}
& D=0.24 \xi_{A}+0.30 \xi_{B}+0.33 \xi_{C}+0.49 \\
& E=0.38 \xi_{C}+0.19 \eta_{D}+0.63
\end{aligned}
$$

Attitude (A) is positively affected by the latent endogenous variable intention (D). The path coefficient between attitude and intention is $\gamma_{D A}=0.24$. A unit increase in the attitude increases their intentions by 0.24 units. The path coefficient between subjective norm (B) and the intention is $\gamma_{D B}=0.30$. A unit increase in the subjective norm increases their intention by 0.30 units. Similarly, it is seen that the latent exogenous variable perceived behavioural control (C) influences the latent endogenous variable, intention (D) and an aspiration towards being an entrepreneur (E). The path coefficient between perceived behavioural control (C) and the $\mathrm{D}$ is $\gamma_{D C}=0.33$. A unit increases in the $\mathrm{C}$ increases their D by 0.33 units. Similarly, the path coefficient between perceived behavioural control (C) and an aspiration towards being an entrepreneur (E) is $\gamma_{E C}$ $=0.38$. Finally, it can be seen that the latent variable, Intention, affects the latent endogenous variable, the aspiration for being an entrepreneur (E), positively, with a path coefficient of $\beta_{E D}=0.19$. In other words, a unit increase in intention (D) would lead to 0.19 units increase in their $\mathrm{E}$. 


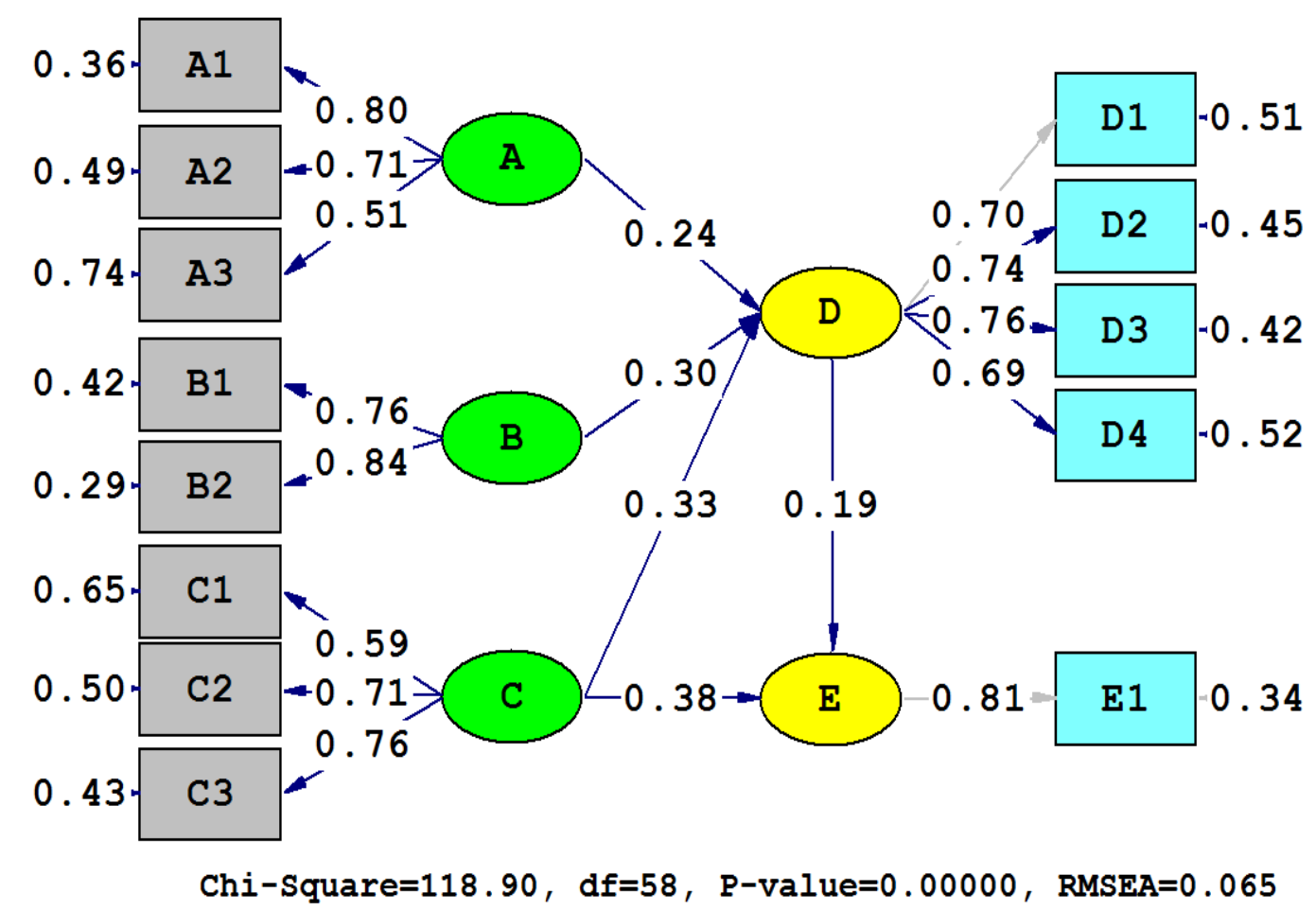

Figure 2. Path Diagram Obtained for The Proposed Research Model (LISREL 8.80 output)

A: Attitude; B: Subjective Norm C: Perceived Behaviour Control; D: Intention

E: An aspiration towards being an entrepreneur

\section{Discussion}

The main object of this study was to reveal, the factors influencing the entrepreneurial intentions of women entrepreneur candidates and the relationship between these factors, by means of a TBP model. Although in literature, the factors that affect entrepreneurship and the studies are in existence that reveal the relations between these factors, it is not encountered too many studies a research model, which is offered in scope of TPB studies. Accordingly, in this study, as distinct from the studies concerning entrepreneurship, it was evaluated that an offered model to reveal the aspiration to be an entrepreneur in the scope of TPB and to add different dimension regards with revealing the aspiration towards SEM analysis.

As a result, it was determined that intention affects aspiration to be an entrepreneur. It is possible to encounter the overlapping studies that findings belong to SEM result of the study. In their study, Koçoğlu and Hasan (2012) on research of entrepreneurship intentions of Turkish and Pakistani students in accordance with TPB model, they came to a conclusion that all components (attitude, individual norms and perceived behaviour control) of TPB has a positive influence on the entrepreneurship intentions of the students in both countries. In our study, it was calculated that the path coefficient between attitudes with regards to entrepreneurship and intention was 0.24 ; path coefficient between subjective norm and entrepreneurial intention was 0.30 ; path coefficient between perceived behaviour control and entrepreneurial intention was 0.33 . Moreover, it was determined that perceived behavioural control and intention factors 
the rise of one unit increase respectively as 0.38 and 0.19 the endogenous latent variable, which identified an aspiration to be an entrepreneur. In the study by Koçoğlu and Hassan (2012), the path coefficients were higher than the result of our study. In the study it was calculated that the path coefficient between subjective attitude and entrepreneurial intention was 0.65 , while the path coefficient between perceived behaviour control and entrepreneurial intention was 0.65 . The only difference between this study and ours, the effect of subjective norm latent variable on entrepreneurial intention is not direct, in that it is revealed by virtue of attitude and perceived behaviour control. Similar to our results, the study by Lo et al. (2012), RPB was used to determine entrepreneurial intentions of women and male engineering students in three universities in Hong Kong, it was established that all components in TPB were effective on entrepreneurial intention. In the study, it was calculated that the path coefficient between subjective attitude and entrepreneurial intention was 0.57 ; the path coefficient between subjective norm and entrepreneurial intention was 0.63 , and the path coefficient between perceived behavior control and entrepreneurial intention was 0.62. It can be seen that the relation parameter of latent variables obtained in the study of Lo et al. (2012) was higher than in our study. In support of the results of the above study, the study made by Kautonen et al. (2015) to examine entrepreneurial intention, it can be seen that components of TPB positively affect the entrepreneurial intention. It was calculated that the path coefficient between attitude and intention was 0.23 ; the path coefficient between subjective norm and intention was 0.54 ; the path coefficient between perceived behaviour control (PBC) and intention was 0.12 and path coefficient between intention and behaviour was 0.49 .

In the study of Liñán and Chen (2009), in which the entrepreneurial intentions of students who were educated in the institution of Technology Innovation Competition in Taiwan and in two universities in Spain, it was determined that personal attitudes, perceived behavior control and subjective norm latent variables positively affect the entrepreneurial intentions of students in both countries; however, in this study, with the differences of our study, it was determined that subjective norm latent variable does not affect intention directly but only indirectly by virtue of personal attitude and PBC (personal behavioural control). Engle et al. (2012), who investigated entrepreneurial intention based upon TPB in 12 countries, similar to the results of our study, stated that subjective norm is an important factor in estimating entrepreneurial intention. Similarly, Krueger et al. (2000) have determined in the study with American students that has a strong effect personal attitude, subjective norm and perceived feasibility on entrepreneurial intention. Shook and Bratianu (2008), with the difference of results of many studies which has been revealed with TPB, in the study that effective factors on 324 Romanian students with the help of TPB model, when the effects of supporters increase, the entrepreneurial intentions decrease. As a result of the study, the regression index between the subjective norm and entrepreneurial intention was found to be -0.13 .

\section{Conclusion}

According to the results of the SEM analysis, it was determined that the latent variables, which are attitudes, subjective norms and perceived behaviour control, have a positive effect on entrepreneurial intentions. In the study, the perceived behavioral control variable was calculated to be $0.38,0.06$ and 0.44 , respectively, direct, indirect and total effect on an aspiration towards being an entrepreneur. It can be said that women entrepreneur candidates with high perceived behavioural control from these 
results are more likely to be an aspiration towards being an entrepreneur. Table 1 shows that the attitude statement with the highest factor load in the attitude statements that measure perceived behaviour control is "I think that my business ideas are creative to be an entrepreneur". In summary, it is determined that the perceived behavior control factor is the most important predictor of entrepreneurial intention and an aspiration towards being an entrepreneur factors.

With the help of the TPB model, this study provides an indication about the extent to which latent variables are effective on the entrepreneurial intentions of women entrepreneur candidates and their aspiration towards becoming an entrepreneur; however, this study includes some constraints that should be the subjects of future studies. It is the constraint for this study that evaluating the women candidates attending to a course centre in a province (Eskişehir) in Turkey for sampling in generalization of the study. In future studies, women candidates that attend in vocational courses in different cities of Turkey and that want to be women entrepreneurs can take part in the sampling process while developing the TPB model by adding extra latent variables in order to extend the research model. Furthermore, in studies going to be discussed, by performing entrepreneurship intentions and wills with different behaviour models out of the TPB scope, results of analysis and relations between latent variables may be compared with the results of the study.

Local authorities can implement affirmative incentives with a view to enable women entrepreneur candidates to realize their expectations on entrepreneurship while contributing the economy of the country. Moreover, the women entrepreneurs club, women associations, non-governmental organizations and chambers of commerce and industry may conduct encouraging activities considering the thoughts of the candidates on entrepreneurship.

\section{References}

Abraham, C., and Sheeran, P. (2003), "Acting on intentions: The role of anticipated regret”, British Journal of Social Psychology, Vol.42 No.4, pp. 495-511.

Ajzen, I. (1988), Attitudes, personality, and behavior. Chicago: Dorsey Press.

Ajzen, I. (1991), "The theory of planned behavior", Organizational Behaviour and Human Decision Processes, Vol.50 No.2, pp.179-211.

Ajzen, I., and Fischbein, M. (1980), Understanding attitudes and predicting social behavior. Englewood Cliffs, NJ: Prentice Hall.

Ajzen, I., and Fischbein, M. (2000), "Attitudes and attitude behavior relation: Reasoned and automatic processes", European Review of Social Psychology, Vol.11 No.1, pp. 1-33.

Arshad, M., Farooq O., Sultana N. and Farooq M. (2016), "Determinants of individuals' entrepreneurial intentions: a gender-comparative study", Career Development International, Vol.21 No.4, pp.318-339.

Autio, E., Keeley, R., Klofsten, M. and Ulfstedt, T. (1997), Entrepreneurial intent among students: testing an intent model in Asia, Scandinavia, and USA, in Sexton, D.L. and Kasarda, J.D. (Eds), Frontiers of Entrepreneurial Research, Babson College Publications, Wellesley, MA, 133-47. 
Autio, E., Keeley, R.H., Klofsten, M., Parker, G. and Hay, M. (2001), "Entrepreneurial intent among students in Scandinavia and in the USA", Enterprise and Innovation Management Studies, Vol.2 No.2, pp.145-160.

Auistin, J.A., and Nauta, M.M. (2016), "Entrepreneurial role- model exposure, selfefficacy, and women's entrepreneurial intentions", Journal of Career Development, Vol.43 No.3, pp.260-272.

Bird, B. J. (1989), Entrepreneurial Behavior. Illinois: Foresman and Company.

Brindley, C. (2005), "Barriers to women achieving their entrepreneurial potential Women and risk", International Journal of Entrepreneurial Behaviour \& Research, Vol.11 No.2, pp-141-161.

Chasserio, S., Pailot, P. and Poroli, C. (2014), "When entrepreneurial identity meets multiple social identities Interplays and identity work of women entrepreneurs", International Journal of Entrepreneurial Behaviour and Research, 20(2), 128154.

Depillis, E., and Reardon, K. (2007), "The influence of personality traits and persuasive messages on entrepreneurial intention: a cross-cultural comparison", Career Development International, Vol.12 No.4, pp.382-396.

Dzisi, S. (2008), Women Entrepreneurs in Small and Medium Enterprises (SMEs) in Ghana, Faculty of Business and Enterprise, Swinburne University of Technology Doctorate Thesis, Victoria, Australia.

Engle, R.L., Dimitriadi, N., Gavidia, J.V., Schlaegel, C., Delanoe, S., Alvarado, I., He, X. Buame, S., and Wolff, B. (2010), "Entrepreneurial intent: A twelve country evaluation of Ajzen's model of planned behavior", International Journal of Entrepreneurial Behaviour and Research, Vol.16 No.1, pp.35-57.

Fischbein, M., and Ajzen, I. (1975), Belief, attitude, intention and behavior: An introduction to theory and research. Reading, MA: Addison-Wesley.

Fayolle, A. (2004), French perspectives of international entrepreneurship, in Dana, L. (Ed.), Handbook of Research on International Entrepreneurship, Edward Elgar, Cheltenham.

Gelderen, M. V., Brand, M., Praag, M.V., Bodewes, W., Poutsma, E. and Gils, A.V. (2008), "Explaining entrepreneurial intentions by means of the theory of planned behavior", Career Development International, Vol.13 No.6, pp.538-559.

Hisrich, R.D., and Peters, M.P. (1998), Entrepreneurship, Irwin Mc Graw Hill, New York.

Iqbal, A., Melhem, Y., and Kokash, H. (2012), "Readiness of the university students towards entrepreneurship in Saudi Private University: An exploratory study", European Scientific Journal, Vol.8 No.15, pp.109-131.

Jöreskog, K., and Sörbom, D. (1996), Lisrel 8: Structural equation modeling, Chicago: Scientific Software International Cop.

Kalkan, A. (2011), "The effect of personal attitude subjective norm and perceived behavioral control on entrpreneurial intention: An application on university students", Süleyman Demirel Üniversitesi Sosyal Bilimler Enstitüsü Dergisi, No.14, pp.189-206. 
Kautonen, T., Gelderen, M., and Tornikoski, E.T. (2013). Predicting entrepreneurial behaviour : a test of theory planned behaviour. Applied Economics, 45(6), 697707.

Kautonen, T., Gelderen, M., and Fink, M. (2015), "Robustness of the theory of planned behavior in predicting entrepreneurial intentions and actions", Entrepreneurship Theory and Practice, Vol.39 No.3, pp.655-674.

Keskin, S. (2014), “Türkiye'de kadın girişimcilerin durumu”, Journal of Entrepreneurship and Development, Vol.9 No.1, pp.71-94.

Koçoğlu, M., and Hassan, M.U. (2013), "Assessing entrepreneurial intentions of university students: A comparative study of two different cultures : Turkey and Pakistani", European Journal of Business and Management, Vol.5 No.13, pp.243252.

Kolvereid, L. (1996), "Prediction of employment status choice intentions". Entrepreneurship Theory and Practice, Vol.20 No.3, pp.47-57.

Kolvereid, L., and Isaksen, E. (2006), "New business start-up and subsequent entry into self-employment", Journal of Business Venturing, Vo.21 No.6, pp.866-885.

Krueger, N. (1993), The impact of prior entrepreneurial exposure on perceptions of new venture feasibility and desirability, Entrepreneurship Theory and Practice, Vol.18 N0.1, pp.5-21.

Krueger, N.F., Jr., Reilly, M.D., and Carsrud, A.L. (2000), "Competing models of entrepreneurial intentions", Journal of Business Venturing, Vol.15 No.5-6, pp. 411-432.

Lee, H.Y., Qu, H., and Kim, YS. (2007), “A study of personal innovativeness on online travel shopping behaviour- a case study of Korean travelers", Tourism Management, Vol.28 No.3, pp.886-897.

Liñán, F., and Chen, Y.W. (2009), "Development and cross-cultural application of a specific instrument to measure entrepreneurial intentions". Entrepreneurship Theory and Practice, Vol.33 No.3, pp.593-617.

Liska, A.E. (1984), "A critical examination of the causal structure of the Fishbein/Ajzen attitude-behaviour model”, Social Psychology Quarterly, Vol.47 No.1, pp.61-74.

Lo, C., Sun, H., and Law, K. (2012), "Comparing the entrepreneurial intention between female and male engineering students", Journal of Women's Entrepreneurship and Education, No.1-2, pp.28-51.

Lounsbury, M. (1998), "Collective entrepreneurship; the mobilization of college and university recycling coordinators", Journal of Organizational Change Management, No.11 No.1, pp.51-60.

Mckenzie-Mohr, D., and Smith, W. (1999), Fostering sustainable behavior: An introduction to community based social marketing, Canada: New Publishers.

Mei, H., Zhan, Z., Fong, P.S.W., Liang, T., and Ma, Z. (2015). Planned behavior of tourism students' entrepreneurial intentions in China. Applied Economics, 48(13), 1240-1254.

Milliyet Newspaper (2014), http://kariyer.milliyet.com.tr/kadinlarin-isgucunekatilimi/kariyer/detay/1780801/default.htm 
Mutlu, S. (2014), "Kosgeb'in uygulamalı girişimcilik sertifikası eğitimi kurslarına katılan kursiyerlerin girişimcilik potansiyelleri ve eğilimleri”, Girişimcilik ve Kalkınma Dergisi, Vol.9 No.1, pp.1-22.

Mueller, S., and Thomas, A.S. (2001), "Culture and entrepreneurial potential: A nine country study of locus control and innovativeness". Journal of Business Venturing, Vol.16 No.1, pp. 51-75.

Özden, K., Temurlenk, M.S. and Başar, S. (2008). "Girişimcilik Eğilimi: KırgızistanTürkiye Manas Üniversitesi ve Atatürk Üniversitesi Öğrencileri Üzerine Bir Araştırma". Review of Social, Economic, and Business Studies, Vol.11 No.12, pp.1-20.

Rajib, Roy, R., Akhtar, F. and Das, N. (2017), "Entrepreneurial intention among science and technology students in India: extending the theory of planned behavior", International Entrepreneurship and Management Journal, DOI 10.1007/s11365017-0434-y.

Schermelleh-Engel, K., Mossbrugger, H., and Müller, H. (2003), "Evaluating the fit of structural equation models: Test of significance and descriptive goodness-of-fit measures". Methods of Psychological Research Online, Vol.8 No.2, pp.23-74.

Shook, C.L. and Bratianu, C. (2010), "Entrepreneurial intent in a transitional economy: an application of the theory of planned behavior of Romanian students", International Entrepreneurship and Management Journal, Vol.6 No.3, pp.231247.

Soysal, A. (2010), "Women entrepreneurs in Turkey: an Assessment in the context of difficulties and opportunities", Ankara Üniversitesi SBF Dergisi, Vol.65 No.1, pp.83-114.

Tkachev, A. and Kolvereid, L. (1999), "Self-employment intentions among Russian students". Entrepreneurship and Regional Development, Vol.11 No.3, pp. 269280.

Turkish Statistical Institution (TUIK-Türkiye İstatistik Kurumu) (2015), Woman Basic Labor Force Indicators. URL: http://www.tuik.gov.tr/PreHaberBultenleri.do?id=18644.

Ministry of Science, Industry and Technology General Directorate of Productivity Monthly Review: Entrepreneurship and Women in Turkey, 2015. Access address: https://anahtar.sanayi.gov.tr/tr/news/turkiyede-girisimcilik-ve-kadin/1970.

Yalman, İ.N. and Gündoğdu, Ö. (2014), “The importance of women entrepreneurships in regional development:The application in TR72 (Kayseri, Sivas, Yozgat) Region”, Journal of Entrepreneurship and Development, Vol.9 No.1, pp39-68.

Yenilmez, G. (2012), Kadın Girişimciler, Karşılaştıkları Sorunlar, Sorunlara Yönelik Çözüm Önerileri: Kütahya Illinde Bir Araştırma. Kobi Uzmanlık Tezi, T.C. Küçük ve Orta Ölçekli İşletmeleri Geliştirme ve Destekleme İdaresi Başkanlığ 1 , Kütahya Hizmet Merkezi Müdürlügü, Kütahya.

Y1lmaz, E., and Sünbül, M. (2009), "Developing scale of university students' entrepreneurship". Selçuk Üniversitesi Sosyal Bilimler Enstitüsü Dergisi, Vol.21 No.2, pp. 195-203. 